Article

\title{
Flow Prediction Using Remotely Sensed Soil Moisture in Irish Catchments
}

\author{
Chanyu Yang ${ }^{1,2}$ and Fiachra E. O'Loughlin ${ }^{3,4, *(1)}$ \\ 1 Key Laboratory of the Three Gorges Reservoir Region's Eco-Environment, Ministry of Education, College of \\ Environment and Ecology, Chongqing University, Chongqing 400045, China; chanyu.yang@ucdconnect.ie \\ 2 School of Civil Engineering, University College Dublin, Dublin, Ireland \\ 3 UCD Dooge Centre for Water Resources Research, School of Civil Engineering, University College Dublin, \\ Dublin, Ireland \\ 4 UCD Earth Institute, University College Dublin, Dublin, Ireland \\ * Correspondence: fiachra.oloughlin@ucd.ie
}

Received: 28 April 2020; Accepted: 29 July 2020; Published: 5 August 2020

\begin{abstract}
Owing to a scarcity of in situ streamflow data in ungauged or poorly gauged basins, remote sensing data is an ideal alternative. It offers a valuable perspective into the dynamic patterns that can be difficult to examine in detail with point measurements. For hydrology, soil moisture is one of the pivotal variables which dominates the partitioning of the water and energy budgets. In this study, nine Irish catchments were used to demonstrate the feasibility of using remotely sensed soil moisture for discharge prediction in ungagged basins. Using the conceptual hydrological model "Soil Moisture Accounting and Routing for Transport" (SMART), behavioural parameter sets (BPS) were selected using two different objective functions: the Nash Sutcliffe Efficiency (NSE) and Coefficient of Determination $\left(\mathrm{R}^{2}\right)$ for the calibration period. Good NSE scores were obtained from hydrographs produced using the satellite soil moisture BPS. While the mean performance shows the feasibility of using remotely sensed soil moisture, some outliers result in negative NSE scores. This highlights that care needs to be taken with parameterization of hydrological models using remotely sensed soil moisture for ungauged basin.
\end{abstract}

Keywords: soil moisture; satellite remote sensing; hydrological modelling; ungauged basins

\section{Introduction}

The conventional ways of monitoring the earth's hydrological circle depends upon in situ spot measurements. While such measurements absolutely provide information about discrete points within a catchment, they may be inadequate for answering specific spatial-scale research questions. In spite of the saying, "Observation is the foundation of all learning", observation of nearly all the process components of hydrology is not easy resulting from explicit routine measurements of evaporation, infiltration and subsurface flow and even rainfall, which are difficult to collect in some circumstances. Elevation of water level in the water bodies and through the inference flow in the water bodies is the one quantity that can be measured confidently and which additionally has the merit to be an integrated measurement with respect of the catchment scale. This is probably the reason that human civilizations have relied so greatly on river gauging to recognize, understand and quantify the response of the landscape to rainfall inputs [1]. However, globally, there are an interesting number of catchments with little or no discharge measurements and the number of gauging stations is continuing to decline [2,3]. To help address this lack of information, the International Association of Hydrological Science undertook and completed its science decade on "Predication in Ungauged Basins" (PUB) in 2013 [1]. PUB aimed to answer how to undertake hydrological modelling with consideration of the following: (1) the same location but under 
changed circumstances (land use/land cover, observed climate and future climate projection); (2) a different location (gauged/ungauged basins); and (3) different spatial/temporal circumstances (gauged or ungauged catchment under changed conditions).

Ungauged basins usually refer to catchments with a lack of meteorological data (e.g., precipitation and evaporation) and/or hydrological data (i.e., discharge or water level). The lack of either dataset makes calibration of hydrological models impossible or extremely difficult. From here on, ungauged basins/catchments will refer to basins without hydrological data. Remote sensing offers a potential solution to prediction in ungauged basins. Satellite altimetry can measure changes in water levels depending on the size of the water bodies $[4,5]$.

Satellite altimetry is fairly well trusted for use in the calibration of hydrological models as their outputs are similar to traditional in situ measurements; however, currently, only the largest rivers and waterbodies are captured. To capture smaller basins, additional alternatives need to be examined. One method is to examine the fluxes occurring inside the catchment and to try to replicate these. One such flux is the change in soil moisture. Soil moisture is a critical variable of the hydrological cycle, which dominates the partitioning of the mass budget and energy flows between the terrain, ocean and the atmosphere; thus, it is of great importance in the assessment of the different components of the water and energy balance [6]. In situ soil moisture has been employed for improving the estimation of initial conditions in flood modelling $[7,8]$, the calibration of hydrological models $[9,10]$ and the simulation of inundation through data assimilation approaches [11-13].

Soil moisture has been successfully retrieved from both microwave and optical/thermal infrared sensors [14-16]. In fact, global soil moisture products from microwave observations have been developed [17,18], such as the Advanced Microwave Scanning Radiometer-EOS (AMSR-E) [19], the advanced Scatterometer (ASCAT) [20], the Soil Moisture and Ocean Salinity (SMOS) [21], the Soil Moisture Active Passive (SMAP) [22] and the European Space Agency's Climate Change Initiative (ESA CCI) soil moisture products [23-25]. Several studies have validated different remotely sensed products with in situ measurements to quantify the accuracy of these soil moisture products [25-29]. Remotely sensed soil moisture has also a significant possibility for enhancing river flow predictions in ungauged basins or rarely gauged basins, as demonstrated by [30] with ERS Scatterometer data, and has been shown to improve and support hydrological and climatic predictions [31,32]. Remotely sensed soil moisture products have been used to calibrate hydrological models, from simple water resources accounting models [33] to complex distributed hydrologic models [34,35] and semi-distributed hydrologic models [36,37] in between. Several studies showed that improvement on streamflow simulations were achieved by calibrating hydrologic models against remotely sensed soil moisture data compared with uncalibrated models, though they also showed less improvement than models calibrated against streamflow measurements $[33,37]$.

Three major limitations of satellite soil moisture products were noted by [6]: (1) the sensed soil layer from the satellites is relatively shallow ( $2-7 \mathrm{~cm}$ deep); (2) the currently available products are characterized by the coarse spatial resolution (approximately $25 \mathrm{~km}$ ); and (3) the quality in regard to certain surface conditions (dense vegetation, frozen soils, snow and mountainous terrain) is relatively low. For these reasons, a number of approaches were developed to deal with them [38] including spatial downscaling techniques [39-41] and simplified methods for root-zone soil moisture estimation from surface measurements [42,43].

In this study, we present the results from using remotely sensed soil moisture for prediction of discharge in Irish catchments. Discharge predictions derived from remotely sensed soil moisture will be compared to those derived from calibration using in situ discharge. The main objectives of this paper are to (1) investigate the potential of using remotely sensed soil moisture for ungauged basins in Ireland and (2) to investigate the change in accuracy between remotely sensed and in situ derived predictions. 


\section{Data and Methodology}

\subsection{SMART Model}

A novel model—the soil moisture accounting and routing for transport model—was developed and informed with the regards to existing model structures, especially the pathway separation of NAM (NedborAfstromnings Model) [44] and the soil layers of the SMARG (model [45,46].

The SMART model is a lumped model forced with precipitation and potential evapotranspiration, and the soil components are represented by six layers of equal depth with the total depth/capacity of the six layers equal to Z. If the soil moisture capacity of a layer is exceeded, excess moves to a deeper layer if feasible or is intercepted by one of the flow pathways other than overland flow [46]. Five different flow pathways are simulated in the model: (1) overland flow (depending on the direct runoff parameter $(\mathrm{H})$ and the relative soil moisture content), (2) drain flow, (3) interflow (depending on soil moisture excess and outflow from the soil layer), (4) shallow groundwater and (5) deep groundwater. These five pathways are routed initially through four routing components and finally a river routing parameter (Figure 1). All parameters and recommended ranges are found in Table 1.

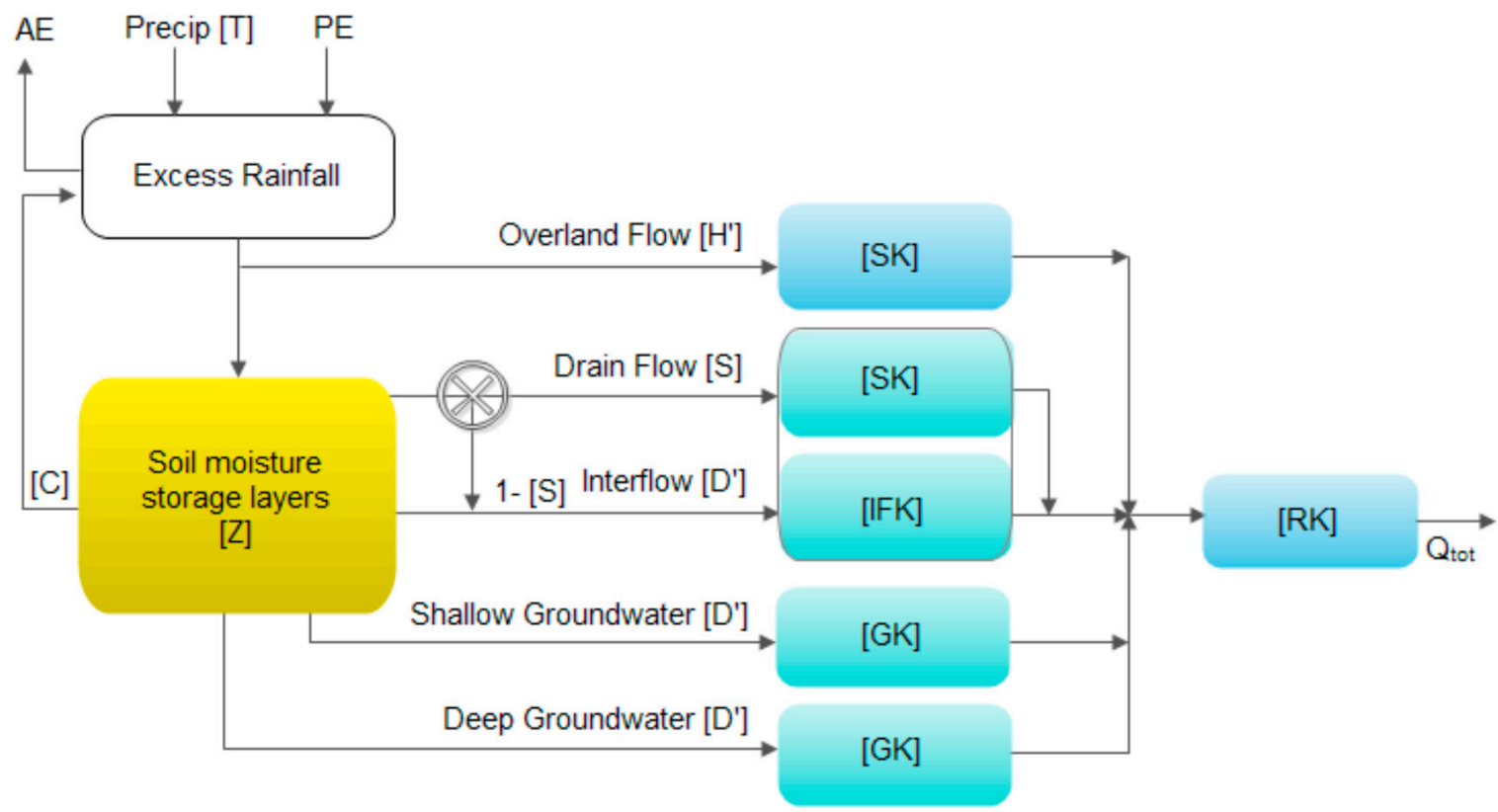

Figure 1. Schematic representation of the Soil Moisture Accounting and Routing for Transport (SMART) model [45].

Table 1. SMART model parameters, descriptions, units and recommended ranges.

\begin{tabular}{ccc}
\hline Parameter & Description & Range \\
\hline T & Areal Rainfall Correction coefficient (/) & $0.9-1.1$ \\
C & Evaporation decay parameter (/) & $0-1$ \\
H & Quick runoff coefficient (/) & $0-0.3$ \\
S & Drain flow parameter (/) & $0-1$ \\
D & Soil outflow coefficient (/) & $0-0.013$ \\
Z & Effective soil depth (mm) & $15-150$ \\
SK & Surface routing parameter (hours) & $1-240$ \\
FK & Interflow routing parameter (hours) & $48-1440$ \\
GK & Groundwater routing parameter (hours) & $1200-4800$ \\
RK & River routing parameter (hours) & $1-96$ \\
\hline
\end{tabular}




\subsection{Study Catchments}

Nine Catchments in Ireland were selected with the aim of representing the various geography, topography and meteorology conditions. Name, gauged area and location of these catchments are presented in Figure 2 and Table 2. The gauging locations chosen are the furthest downstream gauges, where discharge measurements are available for the period of this study. These study catchments were also used in previous studies looking at hydrological modelling in Ireland either in full [45] or a subset [46,47].

Table 2. Study catchments including catchment size, nearest synoptic station and discharge gauge.

\begin{tabular}{ccccc}
\hline Catchment Name & Gauged Area $\left.\mathbf{( k m}^{2}\right)$ & Synoptic Station Name & $\begin{array}{c}\text { Discharge Gauge } \\
\text { Number }\end{array}$ & $\begin{array}{c}\text { Discharge Gauge } \\
\text { Name }\end{array}$ \\
\hline Barrow & 2433 & Casement & 14,018 & Royal Oak \\
\hline Blackwater & 2315 & Cork Airport & 18,002 & Ballyduff \\
\hline Boyne & 2467 & Dublin Airport & 7012 & Slane Castle \\
\hline Dee & 305 & Dublin Airport & 6013 & Charleville \\
\hline Feale & 648 & Valentia Observatory & 23,002 & Listowel \\
\hline Moy & 1908 & Belmullet & 34,001 & $\begin{array}{c}\text { Rahans (Goswami } \\
\text { and O'Connor) }\end{array}$ \\
\hline Nore & 2380 & Casement & 15,006 & Brownsbarn \\
\hline Suck & 1215 & Shannon Airport & 26,007 & Bellagill \\
\hline Suir & 1565 & Shannon Airport & 16,009 & Cahir Park \\
\hline
\end{tabular}

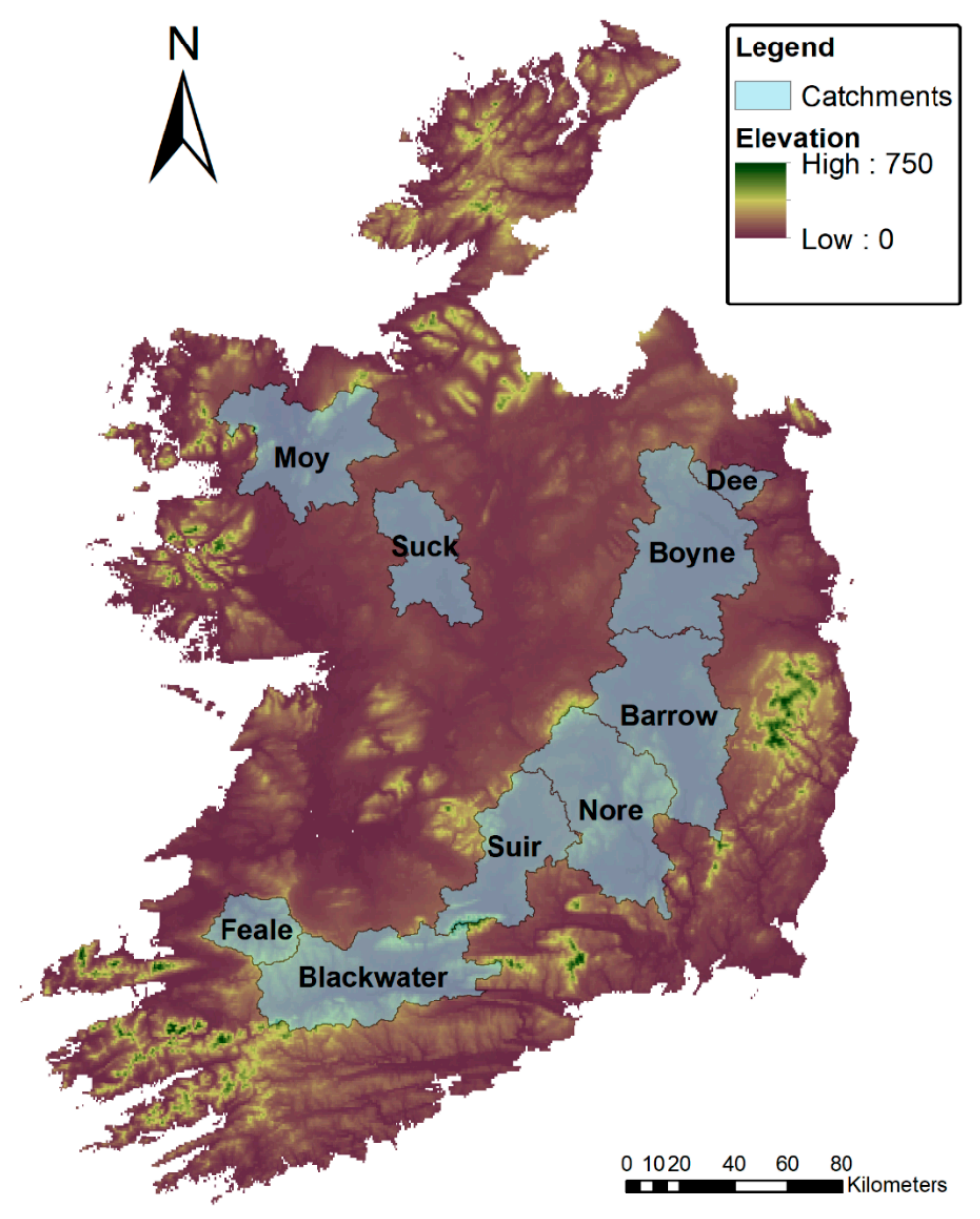

Figure 2. Study catchments with elevation. 


\subsection{Meteorological Data}

To run the SMART model, both rainfall and potential evapotranspiration (PET) are required. Daily rainfall data for relevant rain gauges were obtained from Met Éireann, the Irish meteorological office. These daily point rainfall estimates were converted into catchment average rainfall using the Thiessen Polygon method. For the nine study catchments, the annual average rainfall varied from $864.2 \mathrm{~mm}$ to $1392.7 \mathrm{~mm}$.

Potential evapotranspiration was also obtained from Met Éireann. Met Éireann estimates PET using the FAO Penman-Monteith formula. However, unlike for rainfall, there are fewer locations where PET is measured. Therefore, PET for each catchment was estimated by taking the values from the nearest synoptic station. Table 2 lists the chosen synoptic stations for each catchment. Annual average PET across the six stations varies from $526.6 \mathrm{~mm}$ to $581.1 \mathrm{~mm}$.

\subsection{Discharge}

Daily mean discharge records from 1990 to 2005 were collected from the furthest downstream active gauge of each catchment. This data was obtained from the Irish Office of Public Works (OPW), and this data is freely available at https://waterlevel.ie/hydro-data/. There was on average $5.3 \%$ missing data from all nine gauges with a gauge number 26,007 on Suck recording the largest amount of missing data with $22.24 \%$.

\subsection{Soil Moisture}

The soil moisture data were collected from the Global ASCAT Surface Soil Moisture Data Service belonging to the GEO Department of TU Wien, who have been investigating and constantly improving algorithms for retrieving soil moisture data from C-band scatterometer measurements since the mid-1990s [48].

The data of surface soil moisture are retrieved from the radar backscattering coefficients measured by the ASCAT (advanced scatterometer) instrument on board the MetOp-A satellite using a change detection method, developed at the Research Group Remote Sensing, Department of Geodesy and Geoinformation (GEO), Vienna University of Technology (TU Wien).

The soil moisture product represents the water content in the upper soil layer $(<2 \mathrm{~cm})$ and in relative units between totally dry conditions $(0 \%)$ and total water capacity $(100 \%)$. The time series are available on a discrete global grid (DGG) with a spatial resolution of $25 \mathrm{~km}$ (grid spacing $12.5 \mathrm{~km}$ ). The temporal sampling rate is irregular (every 1-2 days) and depends on the latitude. More detail on the retrieval methodology is described in [49].

\subsection{Experimental Design and Hypothesis Testing}

After collecting the data, 10,000 parameter sets were generated through the Latin hypercube sampling method with the assumption of uniform distribution of the parameter space. The SMART model was then run at a daily timestep using these parameter sets to generate 10,000 unique simulations for each of the nine catchments included in this study. For each simulation, the discharge $\left(\mathrm{m}^{3} / \mathrm{s}\right)$ and the state of each of the six soil moisture layers $\left(\mathrm{m}^{3}\right)$ were simulated. To investigate the potential benefit of remotely sensed soil moisture in ungauged catchments, for each catchment, the simulations were compared separately to both observed discharge and remotely sensed soil moisture to determine behavioural parameter sets (BPSs). In this study, BPSs were determined as the top $5 \%$ best performing parameters sets in terms of comparison between the simulated and observed discharges and the Nash Sutcliffe efficiency [50] and in terms of $\mathrm{R}^{2}$ comparison between the simulated state of the top soil layer and the remotely sensed soil moisture. A very similar methodology has previously been used [46] and closely resembles the Generalized Likelihood Uncertainty Estimation (GLUE) methodology [51]. 
The simulated period from 1990 to 2005 was separated into three periods: model warm-up (1 January 1990 to 31 December 1990), calibration (1 January 1991 to 30 June 1998) and validation (1 July 1998 to 31 December 2005). The BPSs were chosen using the calibration period and one of the objective functions and compared to both objective functions in validation. This was done for both objective functions separately.

Using the experiment design above, we aim to test three hypotheses during this study:

(1) Calibration using only remotely sensed soil moisture would perform worse than calibrating to discharge data.

(2) Remote sensed soil moisture will only be able to provide small benefits to simulate discharge in ungauged basins, especially in the case of Ireland.

(3) A clear relationship between catchment size and model perform will be exhibited when using the $\mathrm{R}^{2}$ BPS.

\section{Results}

In total, four different sets of results were produced:

- $\quad$ Calibration using Nash Sutcliffe Efficiency (NSE) and validated using NSE

- Calibration using NSE and validated using $\mathrm{R}^{2}$

- Calibration using $\mathrm{R}^{2}$ and validated using $\mathrm{R}^{2}$

- Calibration using $\mathrm{R}^{2}$ and validated using NSE

\subsection{Calibration by Nash Sutcliffe Efficiency (NSE)}

Figure 3 shows the summary of the behavioural parameter set (BPS) based on NSE for the calibration and validation period with Table 3 giving the mean, standard deviation and maximum NSE and $\mathrm{R}^{2}$ for each catchment in calibration and validation. The results show that the SMART model can reproduce the observed discharge to obtain high NSE values in most catchments and that there is a very small standard deviation across the BPS. The one exception is the Feale catchment for which the median NSE is lower than the others in both calibration and validation. However, there is a small difference if only the best simulation is chosen.

Table 3. Summary statistics (Nash Sutcliffe Efficiency (NSE) and $\mathrm{R}^{2}$ ) for calibration and validation using the NSE behavioural parameter set (BPS) in the format calibration (validation).

\begin{tabular}{ccccccc}
\hline & \multicolumn{3}{c}{ Calibration (Validation) } & \multicolumn{2}{c}{ Calibration (Validation) } \\
\cline { 2 - 7 } & Boyne & Barrow & Nore & Boyne & Barrow & Nore \\
\hline Mean & $0.792(0.824)$ & $0.83(0.842)$ & $0.812(0.806)$ & $0.627(0.472)$ & $0.591(0.452)$ & $0.585(0.464)$ \\
\hline Standard Deviation & $0.025(0.028)$ & $0.023(0.03)$ & $0.028(0.03)$ & $0.029(0.042)$ & $0.038(0.045)$ & $0.038(0.043)$ \\
\hline Max & $0.882(0.911)$ & $0.92(0.929)$ & $0.906(0.898)$ & $0.674(0.578)$ & $0.656(0.552)$ & $0.654(0.556)$ \\
\hline Blackwater & Moy & Suir & Blackwater & Moy & Suir \\
\hline Standard Deviation & $0.024(0.041)$ & $0.013(0.019)$ & $0.022(0.03)$ & $0.034(0.039)$ & $0.035(0.03)$ & $0.034(0.041)$ \\
\hline Max & $0.906(0.914)$ & $0.939(0.952)$ & $0.94(0.912)$ & $0.663(0.49)$ & $0.66(0.51)$ & $0.68(0.513)$ \\
\hline Sun & Suck & Feale & Dee & Suck & Feale & Dee \\
\hline Standard Deviation & $0.016(0.018)$ & $0.064(0.072)$ & $0.029(0.033)$ & $0.045(0.042)$ & $0.049(0.024)$ & $0.026(0.033)$ \\
\hline Max & $0.943(0.95)$ & $0.809(0.817)$ & $0.88(0.917)$ & $0.698(0.546)$ & $0.667(0.438)$ & $0.668(0.554)$ \\
\hline
\end{tabular}

The results for $\mathrm{R}^{2}$ in both the calibration and validation periods using the NSE BPS show similar patterns as the NSE results. The average $\mathrm{R}^{2}$ value across all catchments was 0.604 in the calibration period 
and 0.439 in the validation period. As with the NSE results, Suck performed best for the calibration period with a $\mathrm{R}^{2}$ value of 0.629 and the Feale catchment performed the worst in both periods. As with the NSE results, the results of the $\mathrm{R}^{2}$ analysis, using the NSE BPS, show that catchment size does not have any role in the performance. This is seen in Figure 3 where the catchments are shown in order of catchment size with the Boyne being the largest and the Dee being the smallest.
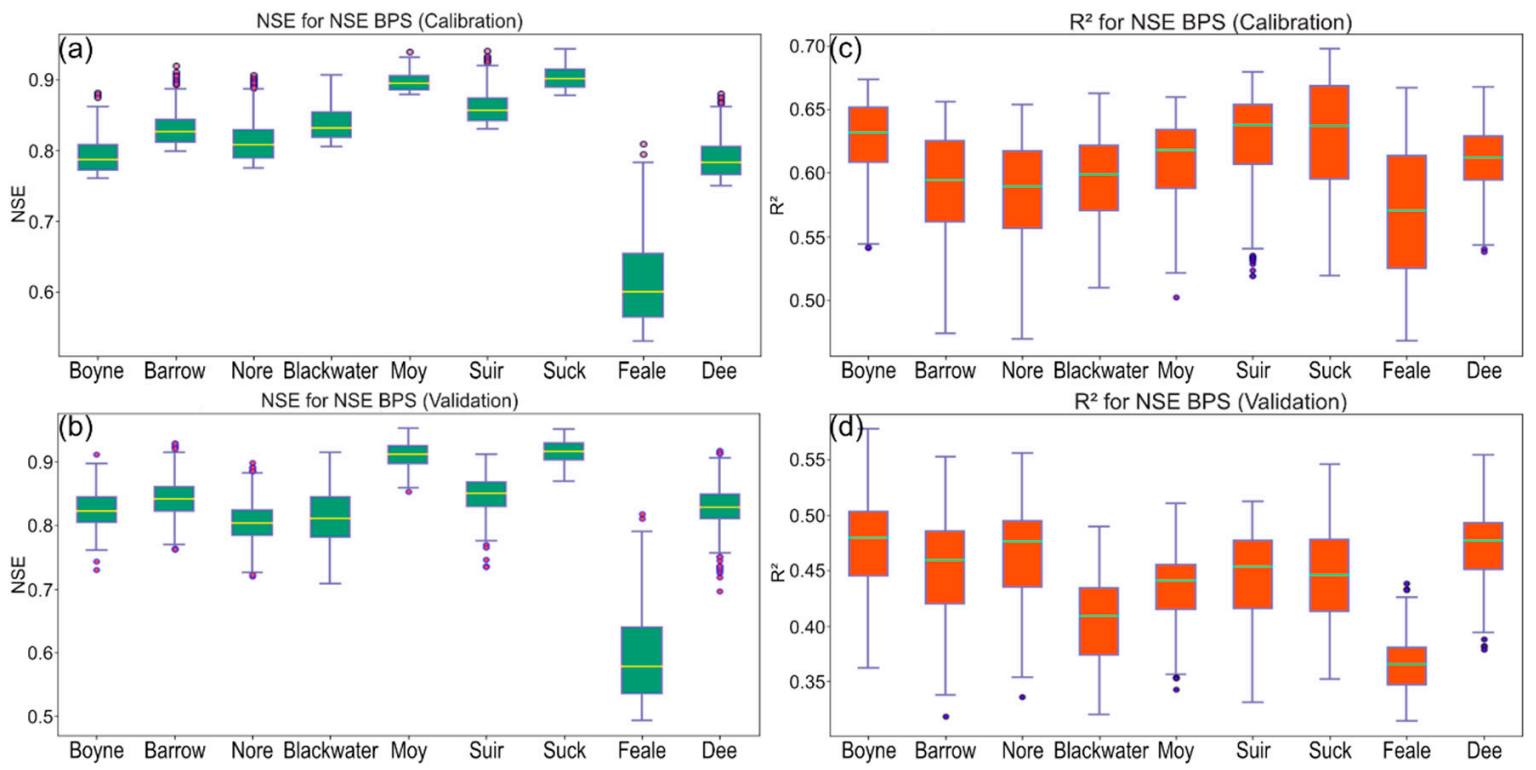

Figure 3. Box plots of NSE and $\mathrm{R}^{2}$ performance using the NSE BPS, (a) NSE results for Calibration;

(b) NSE results for Validation; (c) $R^{2}$ results for Calibration; and (d) $R^{2}$ results in Validation.

Figure 4 shows the mean and standard deviation of all NSE BPS simulations for all nine study catchments compared to in situ observations. With the exception of Feale, it is clearly seen that the mean of the NSE BPS simulations is able to closely reproduce the temporal pattern observed in the in situ observations. This is the case for both high and low flow periods. This is not unexpected as the use of NSE as an objective function is widely used, though it does place more emphasis on high flows.

\subsection{Calibration by $R^{2}$}

The second BPS was obtained by a $\mathrm{R}^{2}$ comparison between the top soil moisture layer in the SMART model and the remotely sensed soil moisture product. Figure 5 and Table 4 show the performance of the $\mathrm{R}^{2}$ BPS in relation to NSE and $\mathrm{R}^{2}$ in both the calibration and validation periods. The results are very similar to those using the NSE BPS with an average $R^{2}$ of 0.653 in the calibration period and 0.488 in the validation period. As with the previous results, Suck is the best performing catchment in the calibration period; however, Feale is no longer the worst catchment in both periods and is the fifth best catchment in the calibration period but the worst in the validation period. As expected, comparing the $R^{2}$ results for both BPS, the spread in performance as measured by the standard deviation is far smaller with the $\mathrm{R}^{2}$ BPS with an order of magnitude difference in the calibration period.

The results for NSE in both the calibration and validation periods using the $\mathrm{R}^{2}$ BPS show a very similar pattern to those using the NSE BPS. The majority of catchments behave very similarly and produce very comparable NSE scores, with Feale being an exception again. The average of the mean performance across all catchments is smaller than those using the NSE BPS at 0.630 and 0.624 in the calibration and validation periods, respectively. However, for the majority of the catchments, with the exception of Feale, there are a number of outliers for which the NSE scores are less than 0 . This indicates that, for some simulations, the performance is worse than the mean discharge. If we ignore outliers, the NSE performance is always greater than 0 . Looking at the interquartile ranges (green area of box plots), the results show that $50 \%$ of the $\mathrm{R}^{2}$ BPS produce NSE scores greater than 0.50 in both the calibration and validation periods. 


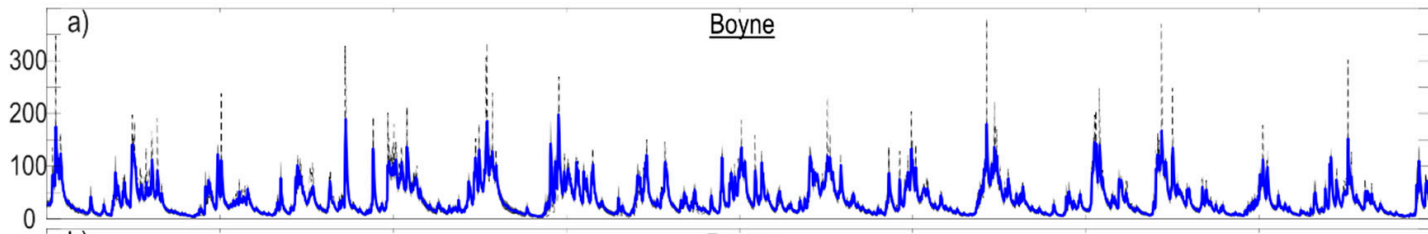

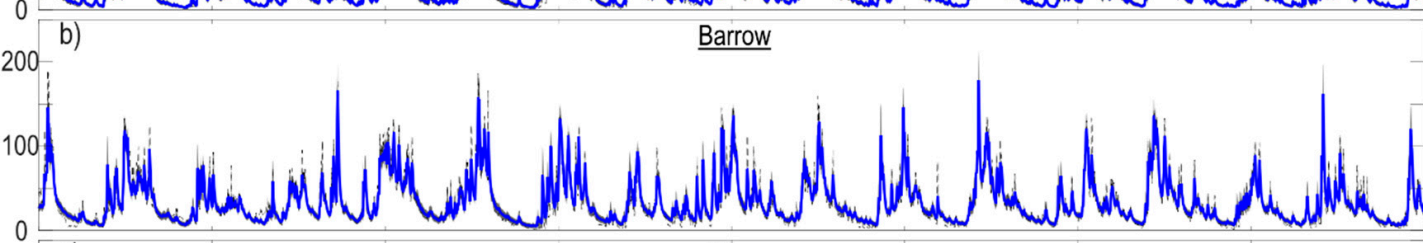
(c) 400 d) Blackwater

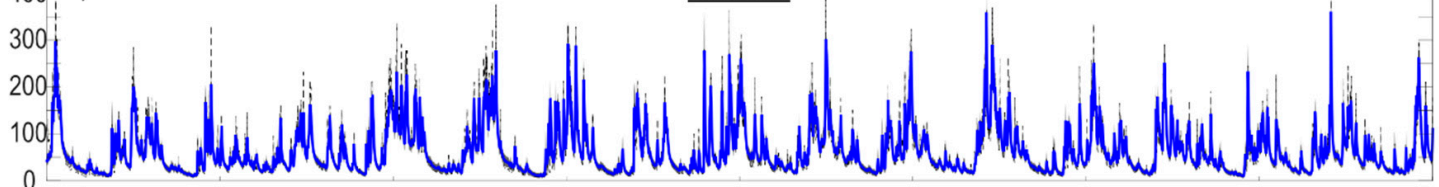

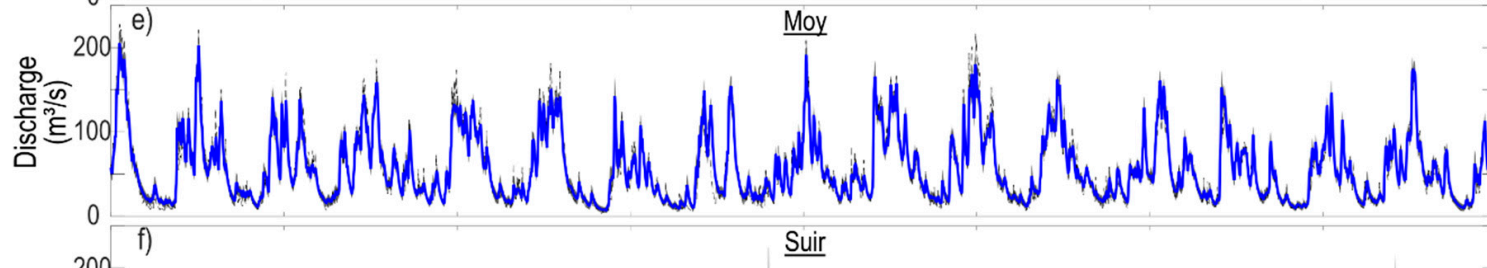

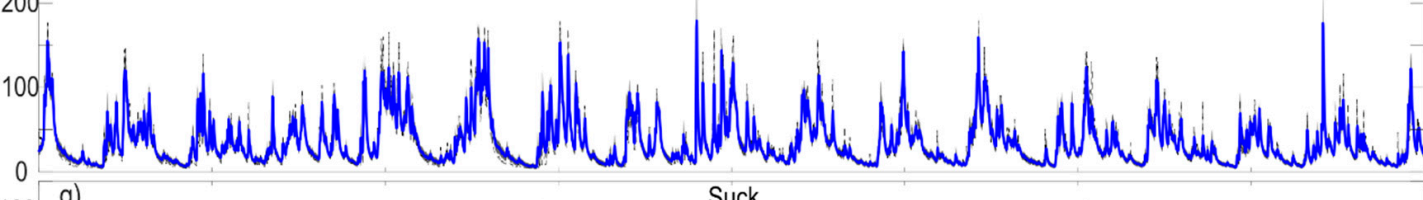

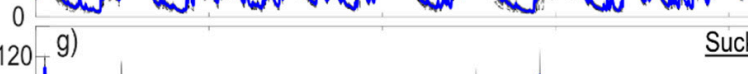

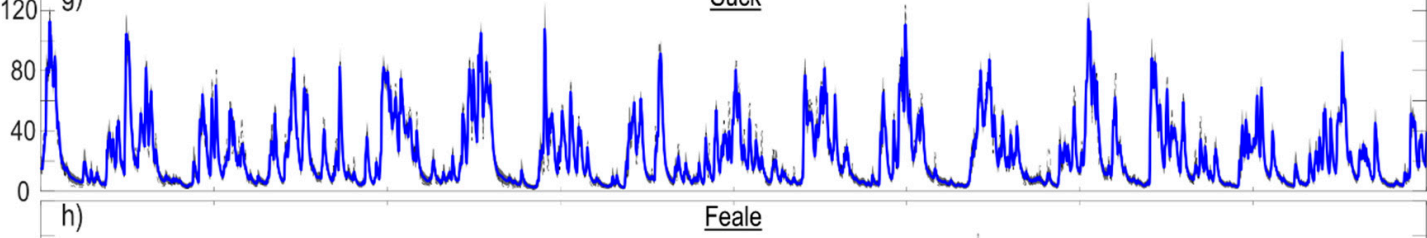

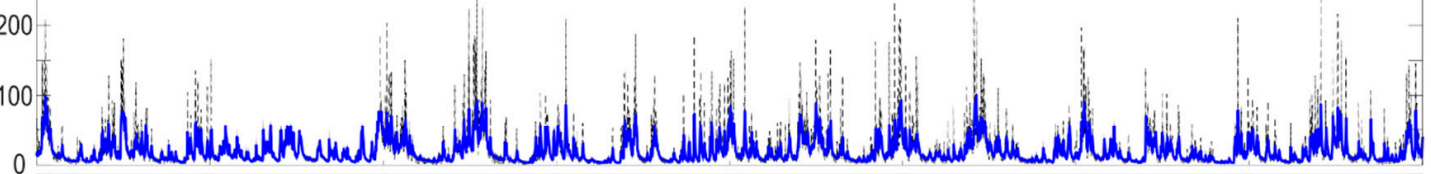

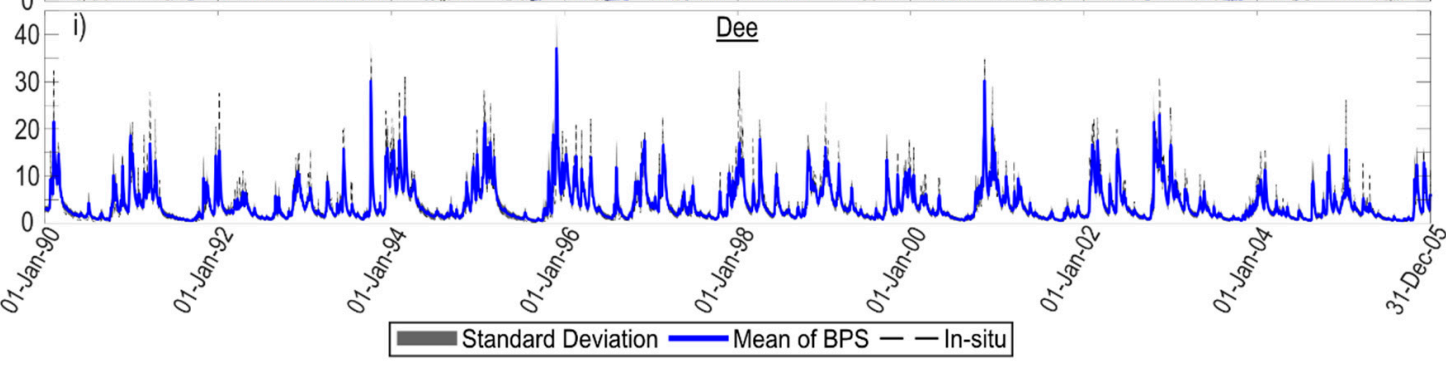

Figure 4. Simulated hydrographs using the NSE BPS compared to in situ observations for all catchments: (a) Boyne; (b) Barrow; (c) Nore; (d) Blackwater; (e) Moy; (f) Suir; (g) Suck; (h) Feale; and (i) Dee. The mean of BPS corresponds to the mean of all BPS simulations. 
Table 4. $\mathrm{R}^{2}$ summary statistics (NSE and $\mathrm{R}^{2}$ ) for calibration and validation using the $\mathrm{R}^{2}$ BPS in the format calibration (validation).

\begin{tabular}{ccccccc}
\hline & \multicolumn{3}{c}{ Calibration (Validation) } & \multicolumn{2}{c}{ Calibration (Validation) } \\
\cline { 2 - 7 } & Boyne & Barrow & Nore & Boyne & Barrow & Nore \\
\hline Mean & $0.650(0.661)$ & $0.679(0.676)$ & $0.661(0.634)$ & $0.661(0.521)$ & $0.639(0.504)$ & $0.634(0.513)$ \\
\hline Standard Deviation & $0.138(0.150)$ & $0.172(0.177)$ & $0.132(0.146)$ & $0.005(0.017)$ & $0.006(0.016)$ & $0.007(0.014)$ \\
\hline Max & $0.882(0.885)$ & $0.92(0.928)$ & $0.906(0.885)$ & $0.679(0.588)$ & $0.662(0.561)$ & $0.661(0.564)$ \\
\hline Blackwater & Moy & Suir & Blackwater & Moy & Suir \\
\hline Standard Deviation & $0.115(0.12)$ & $0.135(0.135)$ & $0.133(0.128)$ & $0.007(0.01)$ & $0.006(0.015)$ & $0.004(0.007)$ \\
\hline Max & $0.901(0.9)$ & $0.922(0.943)$ & $0.94(0.912)$ & $0.672(0.49)$ & $0.682(0.548)$ & $0.68(0.513)$ \\
\hline Suck & Feale & Dee & Suck & Feale & Dee \\
\hline Standard Deviation & $0.161(0.166)$ & $0.119(0.119)$ & $0.15(0.163)$ & $0.005(0.012)$ & $0.006(0.016)$ & $0.007(0.015)$ \\
\hline Max & $0.925(0.939)$ & $0.717(0.717)$ & $0.88(0.915)$ & $0.712(0.551)$ & $0.678(0.457)$ & $0.674(0.561)$ \\
\hline
\end{tabular}
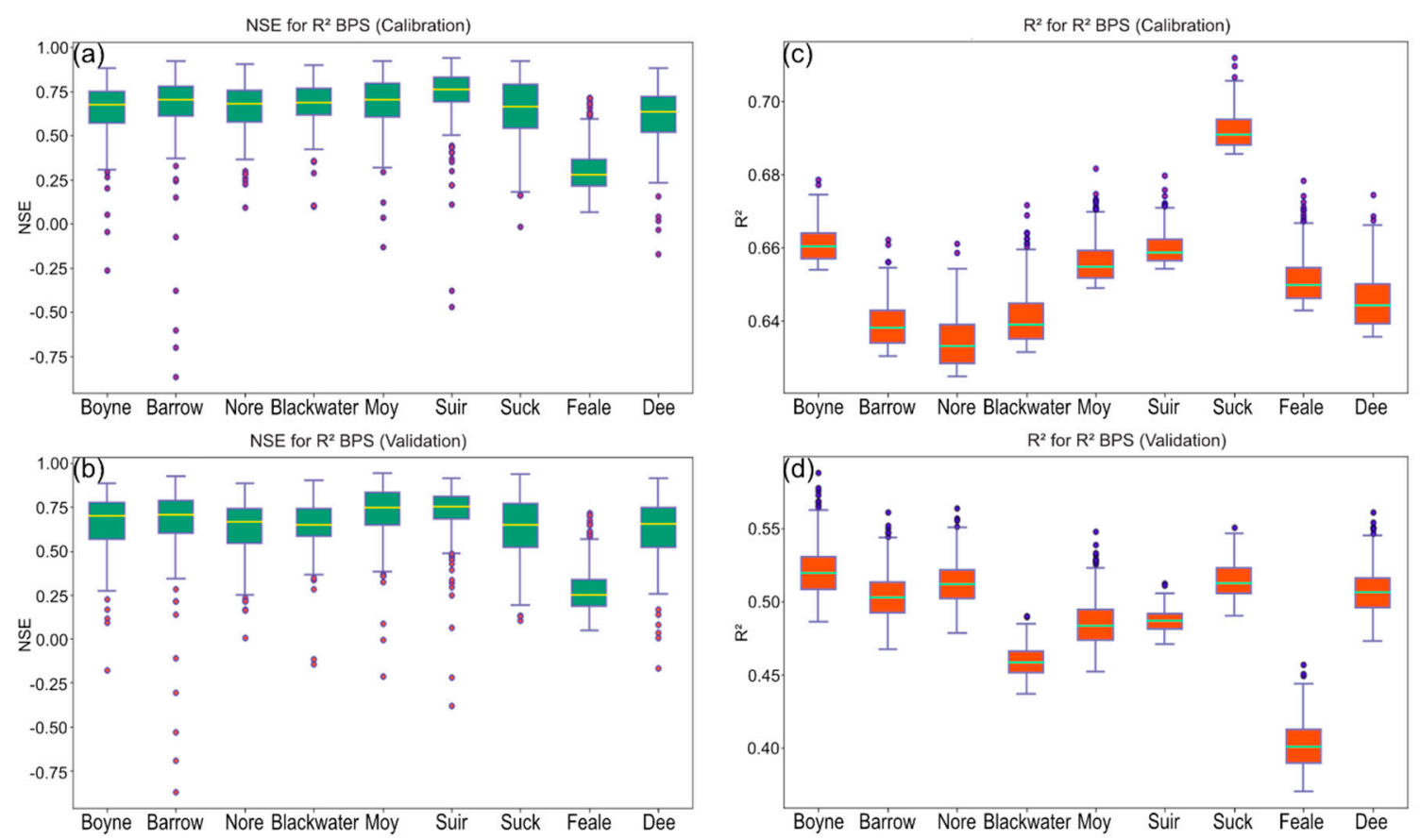

Figure 5. Boxplot of NSE and $R^{2}$ performance using the $R^{2}$ BPS, (a) NSE results for Calibration; (b) NSE results for Validation; (c) $R^{2}$ results for Calibration; and (d) $R^{2}$ results in Validation.

Figure 6 shows the mean and standard deviation of all $\mathrm{R}^{2}$ BPS simulations for all nine study catchments compared to in situ observations. A similar pattern to the hydrographs shown in Figure 4 can be seen in the mean and standard deviation of the $\mathrm{R}^{2}$ BPS simulations, with the Feale catchment performing worse. For all other catchments, it is clearly seen that the simulations perform better for low flow periods than for higher flow periods. This is clearly visible for the larger catchments, such as Nore or Blackwater, where the mean and standard deviation of the $\mathrm{R}^{2}$ BPS are unable to match the observed peak flows but are able to capture the low flow periods. 

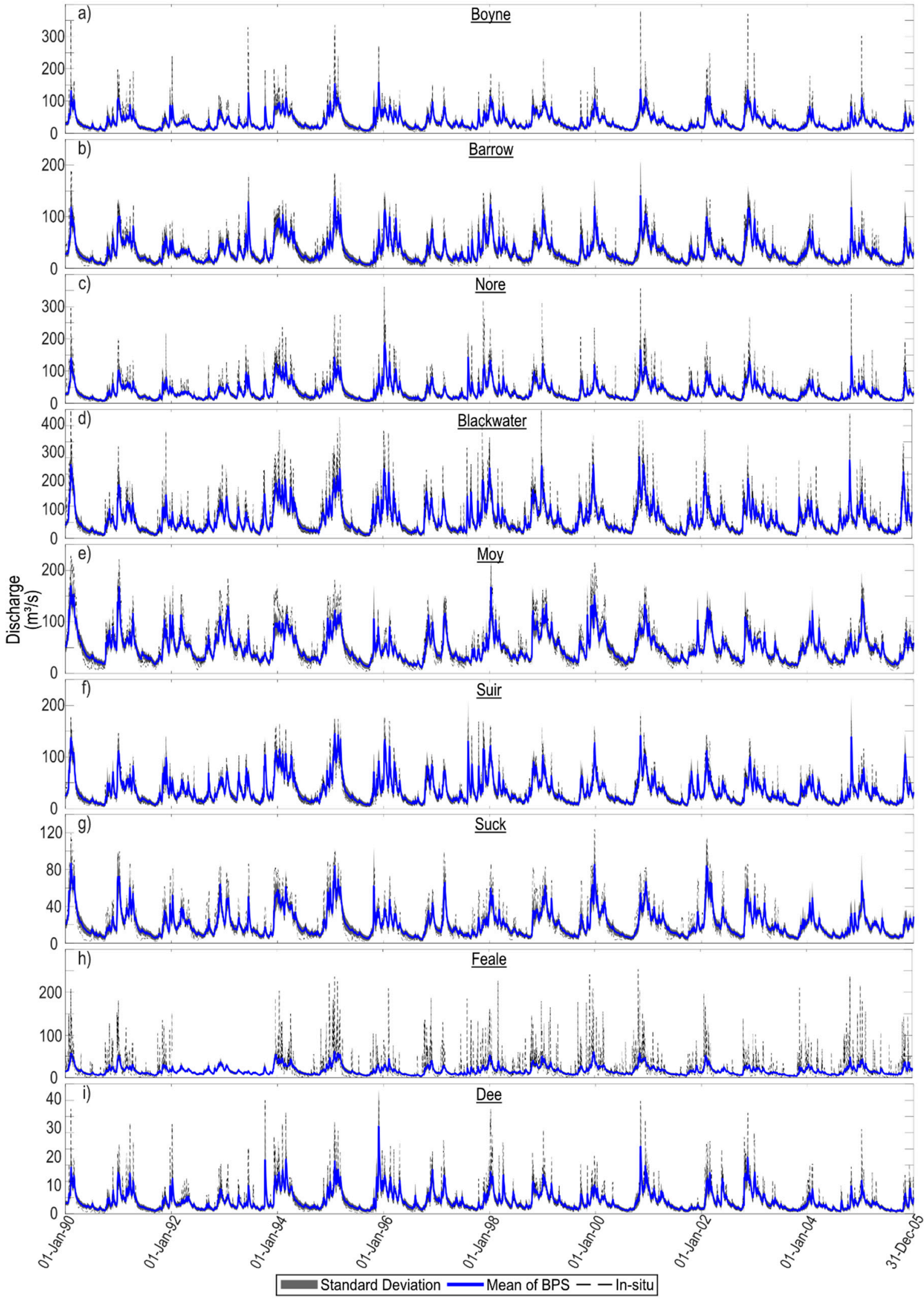

Figure 6. Simulated hydrographs using the $\mathrm{R}^{2}$ BPS compared to in situ observations for all catchments: (a) Boyne; (b) Barrow; (c) Nore; (d) Blackwater; (e) Moy; (f) Suir; (g) Suck; (h) Feale; and (i) Dee. The mean of BPS corresponds to the mean of all BPS simulations. 


\section{Discussion}

\subsection{Hydrograph Comparison}

It is clear from Figures 4 and 6 that the NSE BPS can match the observed temporal variation in discharge better than the $\mathrm{R}^{2}$ BPS. Both BPSs were able to capture low flow periods within the one standard deviation of the mean of all simulations, while the $\mathrm{R}^{2}$ BPSs were unable to match either the NSE BPS or the observations during high flows. However, this is expected as the NSE BPSs were determined by comparing simulated discharge to in situ observations while the $\mathrm{R}^{2}$ BPSs were determined by comparing the top soil layer in the SMART model to remote sensed soil moisture estimates. Therefore, in the case of the $\mathrm{R}^{2} \mathrm{BPS}$, no information the hydrograph response was used.

\subsection{Hypothesis Tests}

Prior to analysing the results, it was hypothesized that calibration of the SMART model using only soil moisture from satellite remote sensing would (1) perform worse than calibrating to discharge data; (2) provide only a small benefit to simulate discharge in ungauged basins, especially in the case of Ireland; and (3) exhibit a clear relationship with catchment size.

By comparing the results of the two sets of behavioural parameters, it is clear that hypothesis 1 is true but not to the scale expected. A far larger difference in performance was expected, as the catchments studied were relatively small compared to the spatial footprint of the soil moisture data. The spatial footprint of the soil moisture product is $625 \mathrm{~km}^{2}$, while the catchments studied varied between $305 \mathrm{~km}^{2}$ and $2467 \mathrm{~km}^{2}$. Using the NSE BPS, the average of NSE performance across all catchments was 0.815 and 0.820 in the calibration and validation periods, respectively, while the performances across the same two period using the $\mathrm{R}^{2} \mathrm{BPS}$ were 0.630 and 0.624 . While this clearly shows that calibrating with discharge data is superior than calibrating with remotely sensed soil moisture data, it does show that, for the nine catchments in this study, soil moisture is a very important model state in simulating discharge. This is also supported by Figures 4 and 6 .

This also disproves our second hypothesis that remotely sensed soil moisture would only have a small benefit in ungauged catchments. Across all the catchments calibrated using the $\mathrm{R}^{2}$ BPS, the SMART model was able to produce simulated hydrographs that produced good NSE scores. The calibration of the SMART model with only remotely sensed soil moisture was able to simulate realistic hydrographs, as shown in Figure 6, though higher flows may be underestimated if only remotely sensed soil moisture for calibration is used and though in an ungauged catchment this might be the only information available. There were a small number of behavioural parameter sets that resulted in negative NSE values, indicating that, for these small number of simulations, the performances were worse than the mean discharge; however, these did not result in the mean and standard deviations of all $\mathrm{R}^{2}$ BPS simulation being unusable.

As previously stated, it was expected that there would be a clear relationship between catchment size and the benefit of remotely sensed soil moisture. It was expected, based off a previous study [52], that the larger catchments would produce better results than smaller catchments in the study. The results would indicate that there is no relationship between remote sensed soil moisture, catchment size and model performance. From the results, it is clear that the result using the $\mathrm{R}^{2}$ BPS follow the same pattern as the NSE BPS. Neither set exhibits any relationship with catchment size, and both sets performed poorly for the same catchment (Feale).

\subsection{Limitation and Future Work}

In this study, nine catchments were chosen for the purpose of this research. These were chosen to be representative of the geography, meteorology and topography of Ireland. No strong inference to the value of remotely sensed soil moisture for smaller catchments can be made from this study, as the smallest catchment chosen was Dee for which catchment area is $305 \mathrm{~km}^{2}$. However, a previous study [52] noted that it is better to choose catchments where the area is greater than one pixel of the remote sensing product. Four catchments (Boyne, Barrow, Nore and Blackwater) were chosen in which 
the catchment areas are greater than $2000 \mathrm{~km}^{2}$ and these cover the majority of the large Irish rivers. Catchments that are heavily influenced by Karst features were also excluded from this study.

Any further study should try to address the limitations mentioned and investigate if the value of remotely sensed soil moisture is consistent throughout larger catchments, if including more layers in the analysis would improve the results, if including existing methods of estimating soil moisture to depths of $1 \mathrm{~m}$ have any benefit and if the results are model dependent.

\section{Conclusions}

Nine gauged catchments across Ireland with catchment areas ranging from $305 \mathrm{~km}^{2}$ to $2467 \mathrm{~km}^{2}$ were chosen to investigate the feasibility of discharge prediction in ungauged basins using only remotely sensed soil moisture. A lumped conceptual hydrological model, the Soil Moisture Accounting and Routing for Transport (SMART) was calibrated and validated by observed discharge and remotely sensed soil moisture using the Nash Sutcliffe Efficiency (NSE) and coefficient of determination $\left(R^{2}\right)$ respectively to select Behavioural Parameter Sets (BPS) for each objective function. Using these BPS, three hypotheses were tested: (1) calibration using only remotely sensed soil moisture would perform worse than calibrating to discharge data; (2) remote sensed soil moisture will only be able to provide small benefits to simulate discharge in ungauged basins, especially in the case of Ireland; and (3) a clear relationship between catchment size and model performance will be exhibited when using the $\mathrm{R}^{2}$ BPS.

From the results, hypothesis 1 was proven true but to a smaller degree than expected. Calibrating the SMART model using remotely sensed soil moisture was able to simulate hydrographs that captured the low flows though underestimated the peak flow while still obtaining good NSE values (on average 0.630 across all nine catchments in the calibration period). Hypothesis 2 was disproven. Simulated hydrographs using parameter only estimated from remotely sensed soil moisture was able to closely reproduce the temporal variation of the in situ observations, though performing better at low flow periods compared to peak flows. Finally, the third hypothesis was disproven. It was assumed that a relationship in performance and catchment size would be visible in the results, especially when using remotely sensed soil moisture. However, this relationship was not apparent with either objective function or in the simulated hydrographs.

Care must be taken using only remotely sensed soil moisture for calibration as it provides no information on the hydrological response of the river, which is necessary to accurately capture peak flow. Nonetheless, this study found that remotely sensed soil moisture is feasible for the parameterization of hydrological model for use in ungauged basins.

Author Contributions: Conceptualization, F.E.O.; methodology, C.Y. and F.E.O.; simulations, C.Y.; data Analysis, C.Y. and F.E.O.; original draft preparation, C.Y.; review and editing, F.E.O.; visualization, C.Y.; supervision, F.E.O. All coauthors reviewed the manuscript prior to and during the submission process to the Water MDPI journal. All authors have read and agreed to the published version of the manuscript.

Funding: This research received no external funding.

Acknowledgments: The authors would like to thank Thibault Hallouin for providing the SMART model code in python for this study.

Conflicts of Interest: The authors declare no conflict of interest.

\section{References}

1. Sivapalan, M. Prediction in ungauged basins: A grand challenge for theoretical hydrology. Hydrol. Process. 2003, 17, 3163-3170. [CrossRef]

2. Fekete, B.M.; Vörösmarty, C.J. The current status of global river discharge monitoring and potential new technologies complementing traditional discharge measurements. IAHS Publ. 2007, 309, 129-136.

3. Shiklomanov, A.; Lammers, R.B.; Vörösmarty, C.J. Widespread decline in hydrological monitoring threatens Pan-Arctic Research. Eos Trans. Am. Geophys. Union 2002, 83, 13. [CrossRef]

4. Becker, M.; Da Silva, J.S.; Calmant, S.; Robinet, V.; Linguet, L.; Seyler, F. Water level fluctuations in the congo basin derived from ENVISAT satellite altimetry. Remote. Sens. 2014, 6, 9340-9358. [CrossRef] 
5. O'Loughlin, F.; Neal, J.; Yamazaki, D.; Bates, P.D. ICESat-derived inland water surface spot heights. Water Resour. Res. 2016, 52, 3276-3284. [CrossRef]

6. Brocca, L.; Ciabatta, L.; Massari, C.; Camici, S.; Tarpanelli, A. Soil moisture for hydrological applications: Open questions and new opportunities. Water 2017, 9, 140. [CrossRef]

7. Massari, C.; Brocca, L.; Moramarco, T.; Tramblay, Y.; Lescot, J.-F.D. Potential of soil moisture observations in flood modelling: Estimating initial conditions and correcting rainfall. Adv. Water Resour. 2014, 74, 44-53. [CrossRef]

8. Tramblay, Y.; Bouvier, C.; Martin, C.; Didon-Lescot, J.-F.; Todorovik, D.; Domergue, J.-M. Assessment of initial soil moisture conditions for event-based rainfall-runoff modelling. J. Hydrol. 2010, 387, 176-187. [CrossRef]

9. Wooldridge, S.; Kalma, J.; Walker, J. Importance of soil moisture measurements for inferring parameters in hydrologic models of low-yielding ephemeral catchments. Environ. Model. Softw. 2003, 18, 35-48. [CrossRef]

10. Koren, V.; Moreda, F.; Smith, M. Use of soil moisture observations to improve parameter consistency in watershed calibration. Phys. Chem. Earth Parts A/B/C 2008, 33, 1068-1080. [CrossRef]

11. Matgen, P.; Fenicia, F.; Heitz, S.; Plaza, D.; De Keyser, R.; Pauwels, V.R.N.; Wagner, W.; Savenije, H. Can ASCAT-derived soil wetness indices reduce predictive uncertainty in well-gauged areas? A comparison with in situ observed soil moisture in an assimilation application. Adv. Water Resour. 2012, 44, 49-65. [CrossRef]

12. Aubert, D.; Loumagne, C.; Oudin, L. Sequential assimilation of soil moisture and streamflow data in a conceptual rainfall-runoff model. J. Hydrol. 2003, 280, 145-161. [CrossRef]

13. Chen, F.; Crow, W.T.; Starks, P.J.; Moriasi, D.N. Improving hydrologic predictions of a catchment model via assimilation of surface soil moisture. Adv. Water Resour. 2011, 34, 526-536. [CrossRef]

14. Peng, J.; Niesel, J.; Loew, A. Evaluation of soil moisture downscaling using a simple thermal-based proxy REMEDHUS network (Spain) example. Hydrol. Earth Syst. Sci. 2015, 19, 4765-4782. [CrossRef]

15. Petropoulos, G.P.; Ireland, G.; Barrett, B. Surface soil moisture retrievals from remote sensing: Current status, products \& future trends. Phys. Chem. Earth Parts A/B/C 2015, 83, 36-56. [CrossRef]

16. Loew, A.; Ludwig, R.; Mauser, W. Derivation of surface soil moisture from ENVISAT ASAR wide swath and image mode data in agricultural areas. IEEE Trans. Geosci. Remote Sens. 2006, 44, 889-899. [CrossRef]

17. Njoku, E.; Jackson, T.J.; Lakshmi, V.; Chan, T.; Nghiem, S. Soil moisture retrieval from AMSR-E. IEEE Trans. Geosci. Remote Sens. 2003, 41, 215-229. [CrossRef]

18. Wagner, W.; Blöschl, G.; Pampaloni, P.; Calvet, J.-C.; Bizzarri, B.; Wigneron, J.-P.; Kerr, Y. Operational readiness of microwave remote sensing of soil moisture for hydrologic applications. Hydrol. Res. 2007, 38, 1-20. [CrossRef]

19. Owe, M.; De Jeu, R.; Holmes, T.R. Multisensor historical climatology of satellite-derived global land surface moisture. J. Geophys. Res. Space Phys. 2008, 113. [CrossRef]

20. Naeimi, V.; Scipal, K.; Bartalis, Z.; Hasenauer, S.; Wagner, W. An improved soil moisture retrieval algorithm for ERS and METOP scatterometer observations. IEEE Trans. Geosci. Remote Sens. 2009, 47, 1999-2013. [CrossRef]

21. Kerr, Y.; Waldteufel, P.; Wigneron, J.-P.; Martinuzzi, J.; Font, J.; Berger, M. Soil moisture retrieval from space: The Soil Moisture and Ocean Salinity (SMOS) mission. IEEE Trans. Geosci. Remote Sens. 2001, 39, 1729-1735. [CrossRef]

22. Entekhabi, D.; Njoku, E.G.; O’Neill, P.E.; Kellogg, K.H.; Crow, W.T.; Edelstein, W.N.; Entin, J.K.; Goodman, S.D.; Jackson, T.J.; Johnson, J.; et al. The Soil Moisture Active Passive (SMAP) mission. Proc. IEEE 2010, 98, 704-716. [CrossRef]

23. Liu, Y.Y.; Parinussa, R.M.; Dorigo, W.A.; De Jeu, R.A.M.; Wagner, W.; Van Dijk, A.I.J.M.; McCabe, M.F.; Evans, J. Developing an improved soil moisture dataset by blending passive and active microwave satellite-based retrievals. Hydrol. Earth Syst. Sci. 2011, 15, 425-436. [CrossRef]

24. Wagner, W.; Dorigo, W.; De Jeu, R.; Fernandez, D.; Benveniste, J.; Haas, E.; Ertl, M. Fusion of active and passive microwave observations to create an essential climate variable data record on soil moisture. ISPRS Ann. Photogramm. Remote Sens. Spat. Inf. Sci. 2012, 7, 315-321.

25. Dorigo, W.; Gruber, A.; De Jeu, R.; Wagner, W.; Stacke, T.; Loew, A.; Calvet, J.-C.; Brocca, L.; Chung, D.; Parinussa, R.; et al. Evaluation of the ESA CCI soil moisture product using ground-based observations. Remote Sens. Environ. 2015, 162, 380-395. [CrossRef]

26. Albergel, C.; De Rosnay, P.; Gruhier, C.; Muñoz-Sabater, J.; Hasenauer, S.; Isaksen, L.; Kerr, Y.; Wagner, W. Evaluation of remotely sensed and modelled soil moisture products using global ground-based in situ observations. Remote Sens. Environ. 2012, 118, 215-226. [CrossRef] 
27. Jackson, T.J.; Bindlish, R.; Cosh, M.H.; Zhao, T.; Starks, P.J.; Bosch, D.D.; Seyfried, M.; Moran, M.S.; Goodrich, D.C.; Kerr, Y.H.; et al. Validation of Soil Moisture and Ocean Salinity (SMOS) soil moisture over watershed networks in the U.S. IEEE Trans. Geosci. Remote Sens. 2011, 50, 1530-1543. [CrossRef]

28. Peng, J.; Niesel, J.; Loew, A.; Zhang, S.; Wang, J. Evaluation of satellite and reanalysis soil moisture products over southwest China using ground-based measurements. Remote Sens. 2015, 7, 15729-15747. [CrossRef]

29. Sanchez, N.; Perez-Gutierrez, C.; Martinez-Fernandez, J.; Scaini, A. Validation of the SMOS L2 soil moisture data in the REMEDHUS network (Spain). IEEE Trans. Geosci. Remote Sens. 2012, 50, 1602-1611. [CrossRef]

30. Parajka, J.; Naeimi, V.; Blöschl, G.; Komma, J. Matching ERS scatterometer based soil moisture patterns with simulations of a conceptual dual layer hydrologic model over Austria. Hydrol. Earth Syst. Sci. 2009, 13, 259-271. [CrossRef]

31. Brocca, L.; Crow, W.T.; Ciabatta, L.; Massari, C.; De Rosnay, P.; Enenkel, M.; Hahn, S.; Amarnath, G.; Camici, S.; Tarpanelli, A.; et al. A review of the applications of ASCAT soil moisture products. IEEE J. Sel. Top. Appl. Earth Obs. Remote Sens. 2017, 10, 2285-2306. [CrossRef]

32. Moran, M.S.; Doorn, B.; Escobar, V.; Brown, M.E. Connecting NASA science and engineering with earth science applications. J. Hydrometeorol. 2015, 16, 473-483. [CrossRef]

33. Kunnath-Poovakka, A.; Ryu, D.; Renzullo, L.; George, B. The efficacy of calibrating hydrologic model using remotely sensed evapotranspiration and soil moisture for streamflow prediction. J. Hydrol. 2016, 535, 509-524. [CrossRef]

34. Sutanudjaja, E.H.; Van Beek, L.P.H.; De Jong, S.; Van Geer, F.C.; Bierkens, M.F.P. Calibrating a large-extent high-resolution coupled groundwater-land surface model using soil moisture and discharge data. Water Resour. Res. 2014, 50, 687-705. [CrossRef]

35. Silvestro, F.; Gabellani, S.; Rudari, R.; Delogu, F.; Laiolo, P.; Boni, G. Uncertainty reduction and parameter estimation of a distributed hydrological model with ground and remote-sensing data. Hydrol. Earth Syst. Sci. 2015, 19, 1727-1751. [CrossRef]

36. Rajib, A.; Merwade, V.; Yu, Z. Multi-objective calibration of a hydrologic model using spatially distributed remotely sensed/in-situ soil moisture. J. Hydrol. 2016, 536, 192-207. [CrossRef]

37. Kundu, D.; Vervoort, R.W.; Van Ogtrop, F. The value of remotely sensed surface soil moisture for model calibration using SWAT. Hydrol. Process. 2017, 31, 2764-2780. [CrossRef]

38. Tebbs, E.; Gerard, F.; Petrie, A.; De Witte, E. Emerging and potential future applications of satellite-based soil moisture products. In Satellite Soil Moisture Retrieval; Petropoulos, G.P., Srivastava, P., Kerr, Y., Eds.; Elsevier: Amsterdam, The Netherlands, 2016; Volume 19, pp. 379-400.

39. Peng, J.; Loew, A.; Merlin, O.; Verhoest, N.E.C. A review of spatial downscaling of satellite remotely sensed soil moisture. Rev. Geophys. 2017, 55, 341-366. [CrossRef]

40. Abbaszadeh, P.; Moradkhani, H.; Zhan, X. Downscaling SMAP radiometer soil moisture over the CONUS using an ensemble learning method. Water Resour. Res. 2019, 55, 324-344. [CrossRef]

41. Piles, M.; Sanchez, N.; Vall-Llossera, M.; Camps, A.; Martinez-Fernandez, J.; Martinez, J.; González-Gambau, V. A downscaling approach for SMOS land observations: Evaluation of high-resolution soil moisture maps over the Iberian Peninsula. IEEE J. Sel. Top. Appl. Earth Obs. Remote Sens. 2014, 7, 3845-3857. [CrossRef]

42. Wagner, W.; Lemoine, G.; Rott, H. A method for estimating soil moisture from ERS scatterometer and soil data. Remote Sens. Environ. 1999, 70, 191-207. [CrossRef]

43. Manfreda, S.; Brocca, L.; Moramarco, T.; Melone, F.; Sheffield, J. A physically based approach for the estimation of root-zone soil moisture from surface measurements. Hydrol. Earth Syst. Sci. 2014, 18, 1199-1212. [CrossRef]

44. Nielsen, S.A.; Hansen, E. Numerical simulation of the rainfall-runoff process on a daily basis. Hydrol. Res. 1973, 4, 171-190. [CrossRef]

45. Mockler, E.M.; O'Loughlin, F.E.; Bruen, M. Understanding hydrological flow paths in conceptual catchment models using uncertainty and sensitivity analysis. Comput. Geosci. 2016, 90, 66-77. [CrossRef]

46. Hallouin, T.; Bruen, M.; O'Loughlin, F.E.; Fiachra, E. Calibration of hydrological models for ecologically relevant streamflow predictions: A trade-off between fitting well to data and estimating consistent parameter sets? Hydrol. Earth Syst. Sci. 2020, 24, 1031-1054. [CrossRef]

47. O'Loughlin, F.; Bruen, M.; Wagener, T. Parameter sensitivity of a watershed-scale flood forecasting model as a function of modelling time-step. Hydrol. Res. 2012, 44, 334-350. [CrossRef] 
48. Wagner, W. Soil Moisture Retrieval from ERS Scatterometer Data; Vienna University of Technology: Vienna, Austria, 1998.

49. Bartalis, Z.; Naeimi, V.; Hasenauer, S.; Wagner, W. ASCAT Soil Moisture Product Handbook; ASCAT Soil Moisture Report Series; Institute of Photogrammetry and Remote Sensing, Vienna University of Technology: Vienna, Austria, 2008.

50. Nash, J.E.; Sutcliffe, J.V. River flow forecasting through conceptual models-part I: A discussion of principles. J. Hydrol. 1970, 10, 282-290. [CrossRef]

51. Beven, K.; Binley, A. The future of distributed models: Model calibration and uncertainty prediction. Hydrol. Process. 1992, 6, 279-298. [CrossRef]

52. Li, Y.; Grimaldi, S.; Pauwels, V.R.N.; Walker, J.P. Hydrologic model calibration using remotely sensed soil moisture and discharge measurements: The impact on predictions at gauged and ungauged locations. J. Hydrol. 2018, 557, 897-909. [CrossRef]

(C) 2020 by the authors. Licensee MDPI, Basel, Switzerland. This article is an open access article distributed under the terms and conditions of the Creative Commons Attribution (CC BY) license (http://creativecommons.org/licenses/by/4.0/). 